\title{
Birds, Migration and Emerging Zoonoses: West Nile Virus, Lyme Disease, Influenza A and Enteropathogens
}

\author{
Kurt D. Reed, MD, Clinical Research Center, Marshfield Medical Research Foundation, Marshfield, Wisconsin \\ Jennifer K. Meece, PhD, Center for Tropical Disease Research and Training, University of Notre Dame, Notre Dame, Indiana \\ and Clinical Research Center, Marshfield Medical Research Foundation, Marshfield, Wisconsin \\ James S. Henkel, BS, University of Wisconsin-LaCrosse, LaCrosse, Wisconsin \\ Sanjay K. Shukla, PhD, Clinical Research Center, Marshfield Medical Research Foundation, Marshfield, Wisconsin
}

[See related article: 37 - 42]

\begin{abstract}
Wild birds are important to public health because they carry emerging zoonotic pathogens, either as a reservoir host or by dispersing infected arthropod vectors. In addition, bird migration provides a mechanism for the establishment of new endemic foci of disease at great distances from where an infection was acquired. Birds are central to the epidemiology of West Nile virus (WNV) because they are the main amplifying host of the virus in nature. The initial spread of WNV in the U.S. along the eastern seaboard coincided with a major bird migration corridor. The subsequent rapid movement of the virus inland could have been facilitated by the elliptical migration routes used by many songbirds. A number of bird species can be infected with Borrelia burgdorferi, the etiologic agent of Lyme disease, but most are not competent to transmit the infection to Ixodes ticks. The major role birds play in the geographic expansion of Lyme disease is as dispersers of $B$. burgdorferi-infected ticks. Aquatic waterfowl are asymptomatic carriers of essentially all hemagglutinin and neuraminidase combinations of influenza $A$ virus. Avian influenza strains do not usually replicate well in humans, but they can undergo genetic reassortment with human strains that co-infect pigs. This can result in new strains with a marked increase in virulence for humans. Wild birds can acquire enteropathogens, such as Salmonella and Campylobacter spp., by feeding on raw sewage and garbage, and can spread these agents to humans directly or by contaminating commercial poultry operations. Conversely, wild birds can acquire drug-resistant enteropathogens from farms and spread these strains along migration routes. Birds contribute to the global spread of emerging infectious diseases in a manner analogous to humans traveling on aircraft. A better understanding of avian migration patterns and infectious diseases of birds would be useful in helping to predict future outbreaks of infections due to emerging zoonotic pathogens.
\end{abstract}

REPRINT REQUESTS:

Kurt Reed, MD

Clinical Research Center

Marshfield Medical Research Foundation

1000 North Oak Avenue

Marshfield, WI 54449

Telephone: 715-389-5478

Fax: 715-389-3319

Email: reed.kurt@marshfieldclinic.org
KEYWORDS:

Birds; West Nile virus; Lyme disease; Influenza A; Enteropathogens; Emerging zoonoses; Migratory patterns 


\section{INTRODUCTION}

Wild birds are important to public health because they can be infected by a number of pathogenic microorganisms that are transmissible to humans (table 1). In addition, birds migrating across national and intercontinental borders can become longrange vectors for any bacterium, virus, parasite, or drugresistant organism they harbor. This creates the potential for the establishment of new endemic foci of disease along migration routes. Among the most important of these disorders are "emerging infectious diseases (EIDs)," i.e., diseases that are newly recognized or previously known diseases that appear in new populations or are rapidly increasing in incidence or geographic range. ${ }^{1}$ In the U.S., the National Institute of Allergy and Infectious Diseases has listed over 30 EIDs that are believed to pose significant risks to human health in the $21^{\text {st }}$ Century. ${ }^{2}$ Wild birds are known to be reservoirs for several of these agents, including arboviruses such as West Nile virus (WNV), Borrelia burgdorferi, influenza A virus, enteric bacterial pathogens, and drug-resistant bacteria. In addition, wild birds can be infested by arthropod vectors, which can drop off and disperse pathogens along migration routes, even if the avian host is not a competent reservoir of infection.

Only recently have the complex inter-relationships between infectious diseases of wildlife, domestic animals, and humans become fully appreciated. ${ }^{3}$ This article reviews important aspects of birds and migration as they relate to the epidemiology of EIDs. The emphasis is on several zoonotic pathogens that are likely to become or remain public health problems in the near future.

\section{BIRD MIGRATION PATTERNS IN NORTH AMERICA}

The seasonal migration of wild birds is one of the most spectacular phenomena of nature. Each autumn an estimated 5 billion birds, representing over 300 species, migrate from North America to Central and South America, and similar numbers travel from Eastern Europe to Africa. ${ }^{4}$ Although there is much to be learned about why some avian species choose to migrate while others do not, one important advantage of migration is the opportunity to exploit seasonal opportunities in breeding habitat and food supplies. From an evolutionary standpoint, the decreased survival associated with the exertion and dangers of long-distant flight seems to be offset by increased reproductive success of migratory bird species. ${ }^{4}$

The ability to predict the spread of EIDs by wild birds in North America requires, at least in part, an understanding of migration patterns for the approximately 650 avian species that breed north of Mexico. ${ }^{5}$ Unfortunately, patterns of migration for wild birds tend to be highly complex and variable between species, and can even be different for distinct populations within the same species. Despite these problems a significant amount of data on bird movements has been collected from bird banding recoveries, netting records and personal observations of field ornithologists. This provides valuable insight into the migration patterns of many bird species. Four broad categories of migration are listed below.

Local species

Bird species that reside in favorable climates, especially tropical and subtropical forests, often live their entire lives within a few miles of where they were hatched. This limited mobility is a strategy that is much less common for birds breeding at higher latitudes. The strongly seasonal climate of North America provides abundant breeding habitat and food supplies in the spring and summer, but cannot sustain the year-

Table 1. Major zoonotic infections of wild birds in North America.

\begin{tabular}{lll}
\hline Disease & Microorganism(s) & Bird species \\
\hline Viral encephalitis $\ddagger$ & Arboviruses (WNV, EEE, SLE, WEE) & $\begin{array}{l}\text { Numerous species (>110) } \\
\text { Crows, Jays, and Raptors are sentinel } \\
\text { species for WNV }\end{array}$ \\
Lyme disease $\ddagger$ & Borrelia burgdorferi sensu stricto & Numerous species of songbirds and waterfowl \\
Influenza $\ddagger$ & Influenza A virus & Waterfowl \\
Enteropathogens $\ddagger$ & Salmonella spp. & Numerous species of songbirds, gulls, and \\
Campylobacter jejuni & wlycopeptide-resistant Enterococcus & waterfowl \\
Mycobacteriosis & Mycobacterium avium & Numerous species \\
Chlamydiosis & Mycobacterium genevense & Psittacine birds, pigeons, poultry
\end{tabular}

¥Organisms on the National Institute of Allergy and Infectious Diseases list of emerging infectious diseases. WNV = West Nile virus; EEE = Eastern equine encephalitis virus; SLE = St. Louis encephalitis virus; WEE = Western equine encephalitis virus. 
round requirements for many bird species. The December 2000 Christmas Bird Count of Wisconsin (an annual inventory of bird species present) revealed 144 species. This compares to the nearly 350 species that are present in Wisconsin, at least intermittently, over the course of an average year. ${ }^{6}$ The potential for long distance spread of infectious diseases by birds that remain local year-round is limited. When spread of infection does occur, it should be in a contiguous fashion unless artificial displacement of infected birds has taken place (e.g., human intervention). The latter is of special concern given the significant amount of legal and illegal transportation of wild animal populations that occurs in the U.S. ${ }^{3}$

\section{Short-distance migrants}

Short distance migrants travel only a few hundred miles or less from their breeding sites to wintering areas. Often they are bird species that have rather extensive summer ranges, and migration concentrates them along the southern aspects of their breeding range during the winter months, or will extend their territory only a short distance further south. For some species, migration is associated more with a change in altitude than horizontal distance. One result of this pattern of migration can be bird species that are confined to a highly restricted area during the winter. Population densities can be an important consideration in the epidemiology of some avian diseases, such as mycoplasma conjunctivitis in house finches, where disease transmission and mortality correlates directly with host density. ${ }^{7}$

\section{Long-distance migrants}

More than 300 species of birds breeding in the United States and Canada spend the winter in the West Indies, Central America, or South America. ${ }^{5}$ These long-distance migrants travel hundreds to thousands of miles from their breeding grounds to wintering ranges. An extreme example of longdistance migration is the Arctic Tern. The intercontinental trip from its circumpolar nesting site to its winter destination at the Antarctic pack ice is nearly 17,000 km long and takes several months to complete (figure 1).

Birds prepare for long-distance migration by increasing energy reserves as stored fat. This is particularly crucial for species like the Blackpoll Warbler, which breeds in the boreal forests of Canada and makes a non-stop flight of 2,500 miles to its wintering range in South America. ${ }^{8}$ Most long-distance migrants make a series of shorter flights, traveling at night when the air is cooler and the atmosphere is generally calmer. Days are used to rest and replenish energy reserves.

Stopovers at these "staging areas" are important from the viewpoint of infectious diseases because they provide the opportunity for close intermingling of species that are otherwise widely separated during the majority of the year. ${ }^{4,8}$ Certain family groups of birds such as geese, swans and cranes use well-established migration corridors through North America. These include the Atlantic, Mississippi, Central and Pacific flyways. These routes are oriented north to south in part because wintering areas are generally located south of breeding sites, but also because the mountain ranges, coasts and major river valleys of North America run in a similar direction. In contrast, many migrating birds in Europe and Asia travel in a more east to west fashion, corresponding to the orientation of major coastlines and other landforms. For most bird species the concept of distinct and narrow migration corridors is an oversimplification of a highly variable process. Numerous variations exist, including elliptical routes, dogleg, or sharply bent migration routes and for some ocean birds, a nomadic wandering that can appear random, but is probably related to poorly understood weather or ocean conditions. ${ }^{9}$

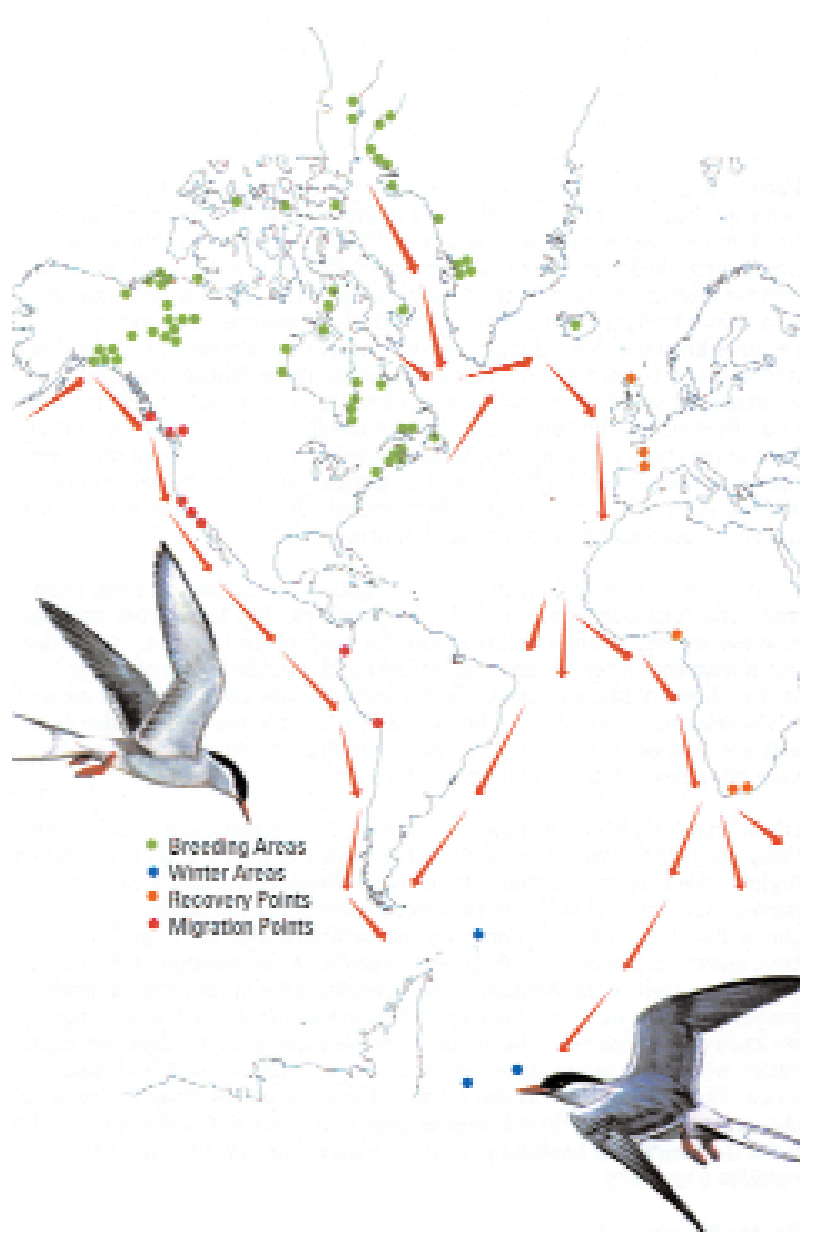

Figure 1. Distribution and migration routes for the Arctic Tern (Sterna paradisaea). An example of inter-hemispheric travel of wild birds. The trip from the breeding ground in the high Arctic to wintering areas at the southern tip of South America and Antarctica covers up to $17,000 \mathrm{~km}$ and takes several months to complete. Other species of ducks and gulls regularly migrate along transatlantic route breeding sites in the Old World to wintering areas along the eastern coast of North America. Map courtesy of the U.S. Department of the Interior and the U.S. Fish and Wildlife Service, Migration of Birds, Circular 16 (Washington, D.C., 1998). 
Several aspects of long-distance migration can contribute to the acquisition of zoonotic pathogens by migrating birds.

Birds that over-winter in the rainforests of Central and South America inhabit, at least intermittently, ecosystems having the greatest biodiversity on earth. The increased biodiversity can be advantageous for a bird species seeking increased food sources and opportunities for shelter. ${ }^{10}$ However, it can also represent increased risk for exposure to the abundance of reservoir hosts and vectors of zoonotic pathogens that abound in tropical regions. Another consideration is the physiologic stress associated with migration, a known risk factor for immunosuppression and increased susceptibility to infectious diseases. For some birds the stress of migration can lead to reactivation of otherwise latent infections. ${ }^{11}$

It is likely that man-made changes to the environment will contribute to changes in the characteristics and patterns of long distance migration. Continued loss and fragmentation of crucial habitat at stopover sites along major migration corridors will create bottlenecks, resulting in increased crowding and intermingling of bird species. In addition, large artificial water impoundments could alter migration corridors for some waterfowl species. These changes and others will undoubtedly have an effect on the ecology of zoonotic pathogens of birds. ${ }^{12}$

\section{Vagrant migration and nomadic wandering}

The year-to-year variation in the movement of certain bird species is highlighted by vagrant migration, an episodic "invasion" into areas that are greatly beyond the normal range. This is most common for species that usually live year round in the far northern latitudes. A classic example is the periodic flights of crossbills that extend well into the southern U.S. In some instances, the stimulus for this nomadic wandering can be attributed to an unusual abundance of food in the new locales. Conversely, a scarcity of the usual food source for the bird species (e.g., the periodic invasion of Snowy Owls correlated with declines in lemmings, their primary food source) can be the trigger. In most cases it can only be assumed that a combination of interrelated ecological factors contribute to this unpredictable pattern of migration. ${ }^{9}$

\section{WILD BIRDS AND THE EMERGENCE OF WNV IN THE WESTERN HEMISPHERE}

WNV is a mosquito-borne virus that can result in fatal encephalitis in humans, horses, and domestic and wild birds. ${ }^{13-15}$ This positive-stranded RNA virus belongs to the Japanese encephalitis complex within the family Flaviviridae. It was first isolated from a woman in the West Nile District of Uganda in $1937 .{ }^{16}$ Since then, the recognized geographic distribution of the virus in the Old World has been found to include much of Africa, Eastern Europe, West Asia and the Middle East. ${ }^{17}$ Outbreaks of WNV infections in humans have been documented in Algeria, Romania, the Czech Republic, the Democratic Republic of the Congo and Russia. ${ }^{18}$ Epizootics involving horses have occurred in Morocco and Italy. 19
The 1999 outbreak of WNV in New York was an unexpected and sobering reminder of the impact an EID can have on public health in the United States. Never before seen in the New World, the initial epidemic resulted in 62 cases of severe encephalitis in humans, including seven deaths. ${ }^{20}$ In addition, significant mortality was noted among horses and numerous species of resident and exotic birds. ${ }^{21}$ Although the 1999 epidemic was tightly confined to the New York City area, the next several years brought rapid expansion of the geographic range of the virus, first along the eastern seaboard and then progressively inland, reaching California in just three years. $^{22,23}$

Wild birds are central to the transmission cycle of WNV because they serve as amplifying hosts for the virus in nature. In the U.S., over 110 avian species, mostly songbirds, have been found to be susceptible to infection. Members of the family Corvidae (crows, jays and magpies) are especially important because they develop severe illness and have a high mortality rate. This makes them useful as sentinels for the presence of virus in new endemic areas. Fortunately most other bird species show few symptoms of infection, but are viremic for several days after exposure and then develop lifelong immunity. ${ }^{24}$ The virus is passed from one bird to another by the bite of ornithophilic mosquitoes, generally Culex spp. Numerous other mosquito species have been shown to be competent vectors of infection. ${ }^{25}$

The mechanism for introduction of WNV to the New World is not known with certainty. One plausible scenario is that infected mosquitoes arrived in the U.S. as stowaways on commercial aircraft or ships. This is unlikely since the percentage of WNV-positive mosquitoes is extraordinarily low, even in areas of active transmission. ${ }^{26}$ It is more likely that the initial outbreak was associated with the arrival of infected birds to the U.S. This could have occurred by normal migration, since several gull and duck species have transatlantic migration routes. Other possibilities include displacement of birds from their normal range by tropical storms or from legal or illegal importation. ${ }^{27}$ It seems less likely that an infected human or domestic animal was the source of introduction. Mammals infected with WNV generally develop low levels of viremia and are incapable of sustaining a transmission cycle in nature. 18

The geographic expansion of the range for WNV in the U.S. from 1999 to 2000 was along the Atlantic seaboard, a common migration route for many bird species that have summer ranges in the northeastern U.S. ${ }^{27}$ Once the infected birds reached southern Florida, a continuous enzootic cycle was established, since mosquitoes are active year-round in subtropical climates. From 2000 to 2002, extension of the endemic area westward occurred faster than what might be predicted for contiguous spread of infection. Rapid spread may have been the result of birds having elliptical migration 


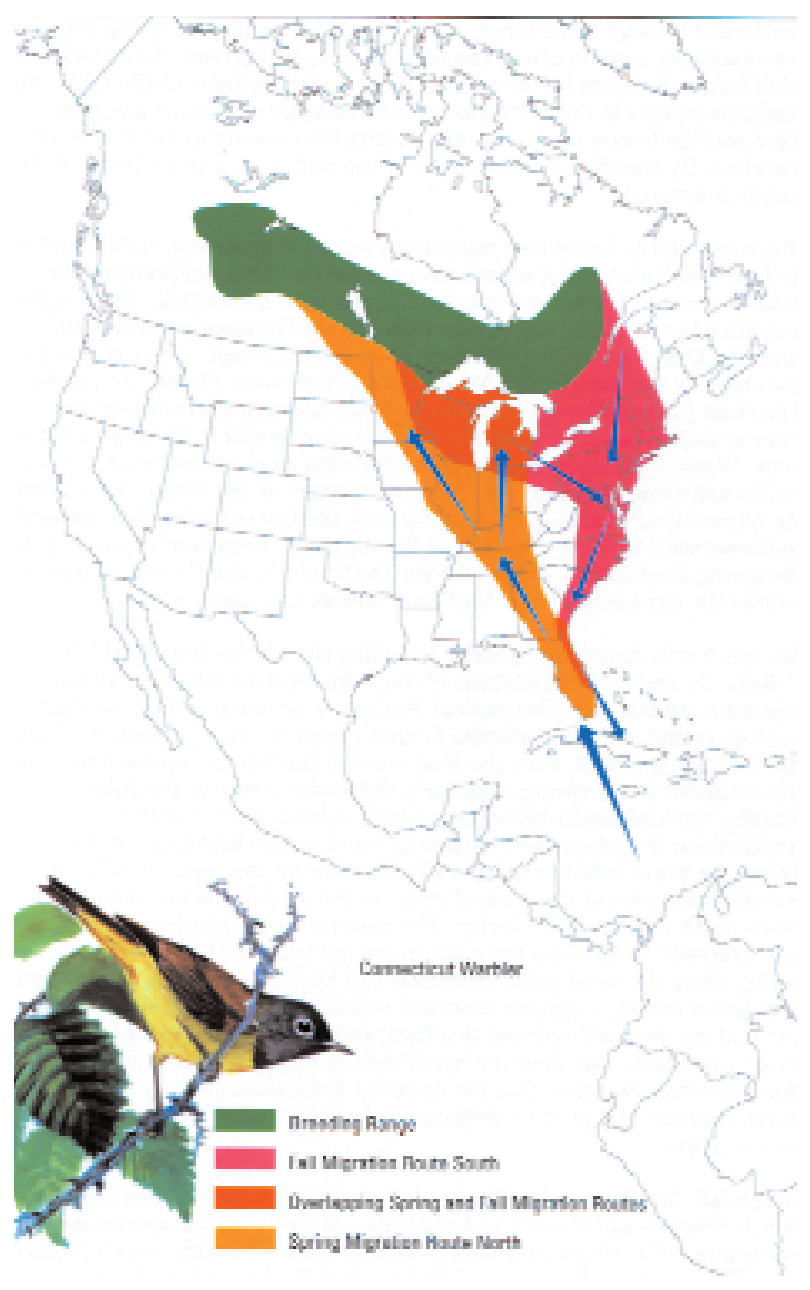

Figure 2. Elliptical migration route for the Connecticut Warbler (Oporornis agilis).

This relatively common pattern of migration for songbirds concentrates them along the Atlantic seaboard during the fall migration, but more inland during the spring. This is a possible mechanism for the western extension of the range for West Nile virus in the United States.

Map courtesy of the U.S. Department of the Interior and the U.S. Fish and Wildlife Service, Migration of Birds, Circular 16 (Washington, D.C., 1998).

routes. These species fly easterly routes on their southern migration, but choose more inland routes during the spring (figure 2).

Three years after the initial outbreak of WNV in New York City, the virus had spread from coast to coast. Suitable conditions for epidemics in humans (densely populated regions with large numbers of susceptible birds and wetland breeding sites for ornithophilic mosquitoes) exist in many areas of the country. The challenge will be to develop models that will allow accurate prediction of potential epidemics in time to intervene with vector control (larviciding or spraying adult mosquitoes), or by vaccinating susceptible individuals when a safe and effective vaccine becomes available.

\section{LYME DISEASE: BIRDS AS DISSEMINATORS OF INFECTED ARTHROPOD VECTORS AND RESERVOIRS OF INFECTION}

Numerous studies have been designed to investigate possible roles wild birds might have in the maintenance of Lyme disease enzootic cycles in nature and for the expansion of endemic ranges. Lyme disease is a multisystem and multistage infection caused by three species of tick-borne spirochetes in the B. burgdorferi sensu lato genogroup. These include $B$. burgdorferi sensu stricto (North America and Western Europe), Borrelia afzelii (Western Europe, Central Europe, and Russia), and Borrelia garinii (Europe, Russia, and Northern Asia). In North America, Lyme disease is perpetuated by enzootic cycles involving rodents, such as whitefooted mice (Peromyscus leucopus) and is transmitted to humans and other animals by Ixodid ticks (Ixodes scapularis in the northeast and north central U.S. and Ixodes pacificus along the pacific coast). ${ }^{28}$

Two important features of the epidemiology of Lyme disease in the U.S. have been the continuous geographic spread of the tick vector and temporal increase in reported cases within endemic areas over the past two decades. For example, tick surveillance around Long Island, NY and Connecticut from 1977 through 1989 indicated that the range of I. scapularis expanded annually into areas over $380 \mathrm{~km}$ away from the original endemic areas. This coincided with an increased incidence of disease reported within previously known endemic counties. ${ }^{29}$

Surveys of ectoparasites of birds reveal that ticks commonly infest a wide range of species, especially thrushes, sparrows and other ground foraging birds. ${ }^{30-34}$ Ticks are usually found attached to the thin skin around the eyes and ears, and on the head - areas that are difficult for the bird to preen (figure 3A). Tick infestation of some birds can be substantial (figure 3B).

Although a wide range of tick species have been reported to parasitize wild birds, Ixodes spp. are the most likely to carry B. burgdorferi. Other species of ticks, such as rabbit ticks (Haemaphysalis leporispalustris) occasionally test positive for $B$. burgdorferi, but the significance of these findings is uncertain. ${ }^{30}$ Ixodid ticks often attach to hosts for 24 to 48 hours while acquiring a blood meal. During migration, this is sufficient time for some birds to travel hundreds or even a few thousand miles before ticks complete feeding and drop off. An example of the capacity for wild birds to carry spirochete-infected ticks long distances is a molecular epidemiologic study which provided evidence of transhemispheric exchange of spirochete-infected ticks by seabirds from colonies in both the southern and northern hemispheres. ${ }^{35}$ Overall, dispersal of B. burgdorferi-infected ticks along migration routes is considered to be an important mechanism for the establishment of new endemic foci of disease. ${ }^{30,32,36}$ 


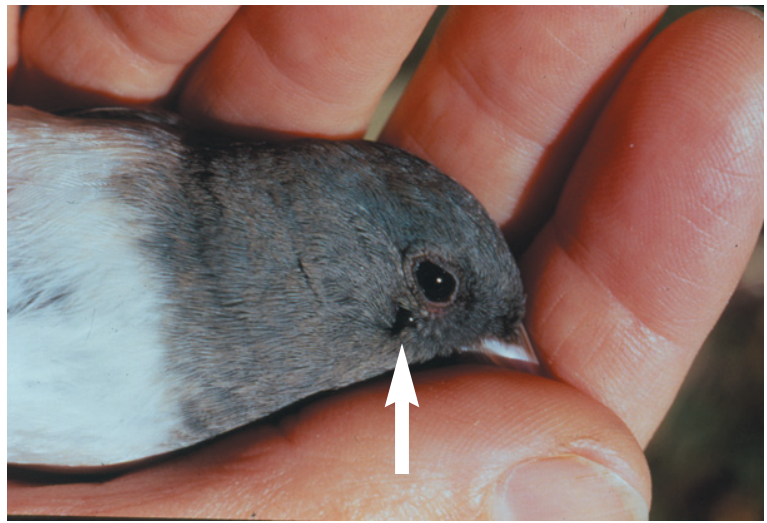

Figure 3A. Engorged Black-legged tick (Ixodes scapularis), the vector of Lyme disease, attached to the skin just below the eye of a Dark-eyed Junco (Junco hyemalis). Ticks attach most frequently to ground-foraging species of birds and tend to concentrate around the ears and eyes, two areas that are difficult for the bird to preen. Photograph courtesy of Dr. Thomas Nicholls

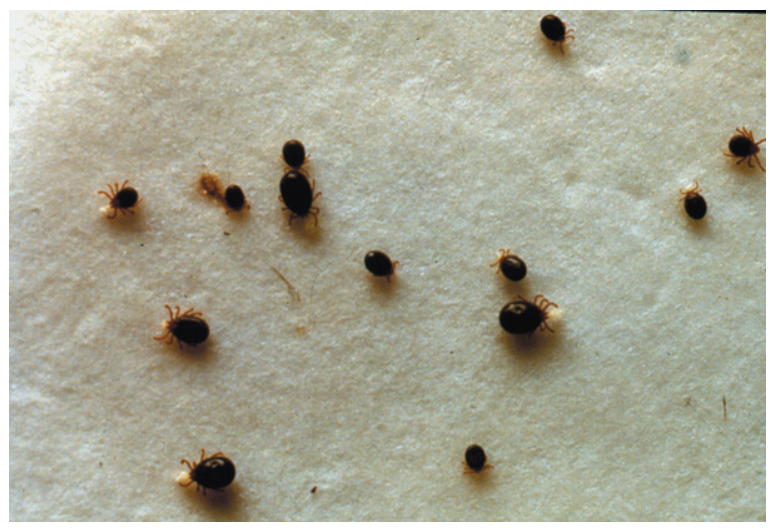

Figure 3B. Multiple engorged ticks removed from a single bird.

Photograph courtesy of Dr. Thomas Nicholls

Another important area of investigation has been attempts to determine whether or not birds might serve as reservoir hosts for B. burgdorferi. Spirochetes have been isolated from the blood of numerous bird species. ${ }^{32,33,36-39}$ However, not all of them seem to be capable of transmitting the infection to tick vectors. ${ }^{40}$ Although wild birds may play a significant role in maintaining enzootic cycles of infection in restricted geographic areas, for most endemic areas rodents are considered more important amplifying hosts in nature.

\section{AQUATIC BIRDS, PIGS, AND PANDEMIC INFLUENZA A VIRUS}

Influenza A virus causes severe respiratory disease outbreaks in a wide variety of animals, including humans, pigs, horses, sea mammals and wild and domestic birds. Worldwide epidemics (pandemics) of influenza have been associated with significant morbidity and mortality in humans, including over 20 million deaths during the devastating outbreak of 1918.41
Two surface glycoproteins on the virus, hemagglutinin and neuraminidase, are important antigens that induce protective immunity in the host, but show significant variation.

Currently, 15 hemagglutinin subtypes and 9 neuraminidase subtypes are recognized. In the last century, the sudden emergence of antigenically different strains (antigenic shift) resulted in four pandemics: 1918 (H1N1), 1957 (H2N2), 1968 (H3N2) and 1977 (H1N1). More frequent and gradual antigenic changes (antigenic drift) have resulted in more limited outbreaks. ${ }^{42}$

For most species, influenza A infections are limited to a relatively small number of hemagglutinin and neuraminidase subtype combinations. However, all subtypes, and most combinations, have been isolated from birds. It is apparent that birds are central to the ecology of influenza A virus because they are asymptomatic during infection, and shed virus for long periods of time. In addition, genetic studies indicate that aquatic birds in particular are the probable source of all influenza A virus strains in other species. ${ }^{41,42}$

Direct transmission of avian strains of influenza A to humans can occur, but in general, aquatic bird strains do not replicate well in humans. Since influenza A virus has a segmented genome, reassortment of gene segments from other strains can help to overcome this host restriction. It has been found that both avian and human strains of influenza replicate well in pigs. It is likely that pigs provide the ideal "mixing vessel" to allow genetic reassortment between co-infecting avian and other mammalian strains to occur. This results in the potential for development of new strains with increased virulence for humans. ${ }^{40}$

The large numbers and close proximity of humans, aquatic birds and pigs in China and Southeast Asia have led to the concept that this region is the epicenter for emerging strains of influenza A virus. Thus, birds that migrate to other parts of the world from the Orient hold significant potential for transmission of novel influenza strains to immunologically naive populations of humans and other animals. ${ }^{44}$

During the late 1990s limited direct transmission of H7N7, $\mathrm{H} 5 \mathrm{~N} 1$, and H9N2 viruses from poultry in live-bird markets in Hong Kong to humans was documented. Fortunately humanto-human transmission of these strains has been limited. 45 Global surveillance of influenza A virus activity in birds, humans and pigs, is currently a major priority of the World Health Organization. These efforts are critical for prevention of the first influenza A pandemic of the $21^{\text {st }}$ Century. 44

\section{BIRDS AS RESERVOIRS OF ZOONOTIC ENTEROPATHOGENS AND ANTIMICROBIAL RESISTANT BACTERIA}

Like other vertebrates, birds are not only susceptible to enteropathogens, but can also transmit these agents to humans. Surprisingly, few comprehensive surveys of micro- 
bial flora have yet been done for wild and most domesticated birds. Salmonella typhimurium is the most commonly reported enteric pathogen of wild birds, and has been associated with significant die-offs of various bird species. Humans have contracted salmonellosis from wild birds via contact with contaminated bird feeders. It has also been postulated that sparrows and other birds that nest or forage around farm buildings can be a source of infection for poultry and other commercial operations. ${ }^{46}$

Limited reports suggest that many birds acquire these infectious agents due to their eating habits or through parasites feeding on them. Numerous bird species (e.g., crows and gulls) are attracted to untreated sewage, garbage dumps, manure, and other sources of enteric pathogens. ${ }^{47}$ Not surprisingly, a number of enteropathogens, such as Salmonella spp. (including the highly virulent serovar DT104), Campylobacter jejuni, Campylobacter coli, and Campylobacter lari have been isolated from intestinal samples of wild birds. ${ }^{46,48}$ Recently, Enterococcus species with high-level glycopeptide resistance were isolated from blackheaded gulls in Sweden and from sub-Antarctic birds from Bird Island in South Georgia. 49

Molecular typing studies have provided some evidence that bird migration may play a role in the spread of antimicrobial resistance. Several $S$. typhimurium strains isolated from wild birds from the southeastern U.S. were found to harbor the same virulence determinants (invasion gene inv $A$ and the plasmid-associated genes $s p v C$ and $p e f$ ) as strains isolated from songbirds in Wyoming. ${ }^{46}$ Multidrug-resistant Salmonella spp. and Campylobacter spp. have also been isolated from wild bird feces. ${ }^{46,48}$ These studies are very preliminary and much work needs to be done to determine the impact wild birds have on zoonotic transmission of enteropathogens and drug-resistant bacteria.

\section{CONCLUSION}

There are complex interrelationships that exist between EIDs of humans, domestic animals and wildlife. Birds have an important role in the transmission and dissemination of several emerging zoonoses of humans. The emergence of WNV in the U.S. is a striking example of how quickly a new zoonotic disease can become widely dispersed. However, there is much to be learned about the specific mechanisms that are involved, and the role wild birds play in human disease is largely understudied. A better understanding of avian migration patterns and infectious diseases of birds would be useful in helping to predict future outbreaks of infections due to emerging zoonotic pathogens.

\section{ACKNOWLEDGMENTS}

The authors thank Dr. Graig Eldred for helpful comments and Alice Stargardt for assistance in preparing the manuscript.

\section{REFERENCES}

1. Institute of Medicine (U.S.). Committee on Emerging Microbial Threats to Health. Lederberg J, Shope RE, Oakes SC Jr, editors. Emerging infections: microbial threats to health in the United States. Institute of Medicine, Washington DC: National Academy Press; 1992.

2. National Institute of Allergy and Infectious Diseases. List of NIAID emerging and re-emerging diseases 2002. http://www.niaid.nih.gov/dmid/eid/erd.htm (10/03/2002).

3. Daszak P, Cunningham AA, Hyatt AD. Emerging infectious diseases of wildlife - threats to biodiversity and human health. Science 2000;287: 443-449.

4. Gill FB. Ornithology. $2^{\text {nd }}$ ed. New York: Freeman; 1994.

5. Rappole JH. The ecology of migrant birds. A Neotropical perspective. Washington DC: Smithsonian Institution Press; 1995.

6. Domagalski RC. The 2000 Wisconsin Christmas bird counts. The Passenger Pigeon 2000;62: 251-281.

7. Hochachka WM, Dhondt AA. Density-dependent decline of host abundance resulting from a new infectious disease. Proc Natl Acad Sci USA 2000;97: 5303-5306.

8. Ehrlich PR, Dobkin DS, Wheye D. The birder's handbook: A field guide to the natural history of North American birds. New York: Simon and Schuster Inc; 1988.

9. Lincoln FC, Peterson SR, Zimmerman JL. Migration of birds. Circular 16. Washington DC: U.S. Department of the Interior, U.S. Fish and Wildlife Service; 1998.

10. Wilson EO. The diversity of life. New York: W.W. Norton \& Co; 1999.

11. Gylfe A, Bergstrom S, Lundstrom J, Olsen B. Reactivation of Borrelia infection in birds. Nature 2000;403: 724-725.

12. Murphy FA. Emerging zoonoses. Emerg Infect Dis 1998;4: 429435.

13. Outbreak of West Nile-like viral encephalitis - New York, 1999. MMWR Morb Mortal Wkly Rep 1999;48: 845-849.

14. Update: West Nile virus encephalitis-New York, 1999. MMWR Morb Mortal Wkly Rep 1999;48: 944-946.

15. Update: West Nile-like viral encephalitis-New York, 1999. MMWR Morb Mortal Wkly Rep 1999;48: 890-892.

16. Smithburn KC, Hughes TP, Burke AW. A neurotropic virus isolated from the blood of a native of Uganda. Am J Trop Med 1940;20: 471-492.

17. Hubalek Z, Halouzka J. West Nile fever-a reemerging mosquito-borne viral disease in Europe. Emerg Infect Dis 1999;5: 643-650.

18. Komar N. West Nile viral encephalitis. Rev Sci Tech 2000;19: 166-176.

19. Tber AA. West Nile fever in horses in Morocco. Bull Off Int Epizoot 1996;108: 867-869.

20. Asnis DS, Conetta R, Teixeira AA, Waldman G, Sampson BA. The West Nile virus outbreak of 1999 in New York: The Flushing Hospital experience. Clin Infect Dis 2000;30: 413418.

21. Steele KE, Linn MJ, Schoepp RJ, Komar N, Geisbert TW, Manduca RM, Calle PP, Raphael BL, Clippinger TL, Larsen T, Smith J, Lanciotti RS, Panella NA, McNamara TS. Pathology of fatal West Nile virus infections in native and exotic birds during the 1999 outbreak in New York City, New York. Vet Pathol 2000;37: 208-224.

22. Centers for Disease Control and Prevention. West Nile virus basics. http://www.cdc.gov/ncidod/dvbid/westnile/ (10/03/2002).

23. Petersen LR, Roehrig JT, Hughes JM. West Nile virus encephalitis. N Engl J Med 2002;347: 1225-1226. 
24. Petersen LR, Roehrig JT. West Nile virus: a reemerging global pathogen. Emerg Infect Dis 2001;7: 611-614.

25. Turell MJ, O'Guinn ML, Dohm DJ, Jones JW. Vector competence of North American mosquitoes (Diptera: Culicidae) for West Nile virus. J Med Entomol 2001;38: 130-134.

26. Nasci RS, White DJ, Stirling H, Oliver JA, Daniels TJ, Falco RC, Campbell S, Crans WJ, Savage HM, Lanciotti RS, Moore CG, Godsey MS, Gottfried KL, Mitchell CJ. West Nile virus isolates from mosquitoes in New York and New Jersey, 1999. Emerg Infect Dis 2001;7: 626-630.

27. Rappole JH, Derrickson SR, Hubalek Z. Migratory birds and spread of West Nile virus in the western hemisphere. Emerg Infect Dis 2000;6: 319-328.

28. Barbour AG. Fall and rise of Lyme disease and other Ixodes tick-borne infections in North America and Europe. $\mathrm{Br}$ Med Bull 1998;54:647-658.

29. White DJ, Chang HG, Benach JL, Bosler EM, Meldrum SC, Means RG, Debbie JG, Birkhead GS, Morse DL. The geographic spread and temporal increase of the Lyme disease epidemic. JAMA 1991;266: 1230-1236.

30. Nicholls TH, Callister SM. Lyme disease spirochetes in ticks collected from birds in midwestern United States. J Med Entomol 1996;33: 379-384.

31. Scott JD, Fernando K, Banerjee SN, Durden LA, Byrne SK, Banerjee M, Mann RB, Morshed MG. Birds disperse ixodid (Acari: Ixodidae) and Borrelia burgdorferi-infected ticks in Canada. J Med Entomol 2001;38: 493-500.

32. Durden LA, McLean RG, Oliver JH, Ubico SR, James AM. Ticks, Lyme disease spirochetes, trypanosomes, and antibody to encephalitis viruses in wild birds from coastal Georgia and South Carolina. J Parasitol 1997;83: 1178-1182.

33. Wright SA, Thompson MA, Miller MJ, Knerl KM, Elms SL, Karpowicz JC, Young JF, Kramer VL. Ecology of Borrelia burgdorferi in ticks (Acari: Ixodidae), rodents, and birds in the Sierra Nevada foothills, Placer County, California. J Med Entomol 2000;37: 909-918.

34. Rand PW, Lacombe EH, Smith RP Jr, Ficker J. Participation of birds (Aves) in the emergence of Lyme disease in southern Maine. J Med Entomol 1998;35: 270-276.

35. Olsen B, Duffy DC, Jaenson TG, Gylfe A, Bonnedahl J, Bergstrom S. Transhemispheric exchange of Lyme disease spirochetes by seabirds. J Clin Microbiol 1995;33: 3270-3274.

36. Anderson JF, Johnson RC, Magnarelli LA, Hyde FW. Involvement of birds in the epidemiology of the Lyme disease agent Borrelia burgdorferi. Infect Immun 1986;51: 394-396.

37. Gylfe OB, Strasevicius D, Marti Ras N, Weihe P, Noppa L, Ostberg Y, Baranton G, Bergstrom S. Isolation of Lyme disease Borrelia in puffins (Fratercula arctica) and seabird ticks (Ixodes uriae) on the Faeroe Islands. J Clin Microbiol 1999;37: 890-896.

38. Humair PF, Postic D, Wallich R, Gern L. An avian reservoir (Turdus merula) of the Lyme borreliosis spirochetes. Zentralbl Bakteriol 1998;287: 521-538.

39. Richter D, Spielman A, Komar N, Matuschka FR. Competence of American robins as reservoir hosts for Lyme disease spirochetes. Emerg Infect Dis 2000;6: 133-138.

40. Mather TN, Telford SR $3^{\text {rd }}$, MacLachlan AB, Spielman A. Incompetence of catbirds as reservoirs for the Lyme disease spirochete (Borrelia burgdorferi). J Parasitol 1989;75: 66-69.

41. Horimoto T, Kawaoka Y. Pandemic threat posed by avian influenza A viruses. Clin Microbiol Rev 2001;14: 129-149.

42. Webster RG. Influenza: an emerging disease. Emerg Infect Dis 1998;4: 436-441.

43. Nichol ST, Arikawa J, Kawaoka Y. Emerging viral diseases. Proc Natl Acad Sci USA 2000;97: 12411-12412.

44. Webby RJ, Webster RG. Emergence of influenza A viruses. Philos Trans R Soc Lond B Biol Sci 2001;356: 1817-1828.
45. Alexander DJ, Brown IH. Recent zoonoses caused by influenza A viruses. Rev Sci Tech 2000;19: 197-225.

46. Hudson CR, Quist C, Lee MD, Keyes K, Dodson SV, Morales C, Sanchez S, White DG, Maurer JJ. Genetic relatedness of Salmonella isolates from nondomestic birds in Southeastern United States. J Clin Microbiol 2000;38: 1860-1865.

47. Butterfield J, Coulson JC, Kearsey SV, Monaghan P, McCoy JH, Spain GE. The herring gull Larus argentatus as a carrier of Salmonella. J Hyg (Lond) 1983;91: 429-436.

48. Chuma T, Hashimoto S, Okamoto K. Detection of thermophilic Campylobacter from sparrows by multiplex PCR: the role of sparrows as a source of contamination of broilers with Campylobacter. J Vet Med Sci 2000;62: 1291-1295.

49. Sellin M, Palmgren H, Broman T, Bergstrom S, Olsen B. Involving ornithologists in the surveillance of vancomycinresistant enterococci. Emerg Infect Dis 2000;6: 87-88. 